American Journal of Agricultural and Biological Sciences 7 (1): 21-27, 2012

ISSN 1557-4989

(C) 2012 Science Publications

\title{
Measuring ICT Usage among West Coast Fishermen: Pre-Test Results from Port Dickson, Negeri Sembilan
}

\author{
${ }^{1}$ Hayrol Azril Mohamed Shaffril, ${ }^{2}$ Siti Zobidah Omar, \\ ${ }^{3}$ Musa Abu Hassan, ${ }^{2}$ Jusang Bolong and ${ }^{1}$ Jeffrey Lawrence D'Silva \\ ${ }^{1}$ Laboratory of Sustainable Development and Agriculture Extension, \\ Institute for Social Science Studies, \\ Universiti Putra Malaysia, Putra Infoport, \\ 43400 Serdang, Selangor Darul Ehsan, Malaysia \\ ${ }^{2}$ Department of Communication, \\ Faculty of Modern Language and Communication, \\ Universiti Putra Malaysia, Malaysia \\ ${ }^{3}$ Faculty of Leadership and Management, \\ University of Science and Islamic Malaysia, Malaysia
}

\begin{abstract}
Problem statement: The government has admitted the effectiveness of ICT in bringing changes to the socio-economic aspects of the community. Groups such as farmers, entrepreneurs, rural community and housewives for examples have been proven by a number of past studies to profit the huge advantages offered by ICT. Nonetheless, there is inadequacy in term of study related to ICT usage among one of the important groups in Malaysia; the fishermen. Before doing a study related to ICT usage among fishermen, a reliable instrument is needed, hence the main purpose of this study is to discuss the reliability and validity of an instrument developed for measuring ICT usage among the fishermen. Approach: This is a quantitative study; the pre-test process took place at Port Dickson, Negeri Sembilan, Malaysia, where a total of 30 registered fishermen were randomly chosen as the respondents. Results: Reliability analysis run has generated cronbach alpha value ranging from 0.7140.970 thus reflect the instrument has a good strength in term of reliability. Conclusion/Recommendations: A number of recommendations have been highlighted which involves trainings to enumerator and a number of modifications on the instrument.
\end{abstract}

Key words: ICT, fishermen, community development, pre test, instrument

\section{INTRODUCTION}

Agriculture is an important economic branch in Malaysia. The significant of this industry has been admitted by the government as this industry is continuously emphasized in each of the Malaysian Plans. In the Ninth Malaysian Plan (9MP) for example, this industry was emphasized as the third income generator for the country. Fisheries industry is one of the main components in the agriculture. It has continued to play an important role in enhancing the socio-economic aspects of the community especially those in the rural areas. In 2009, the fisheries industry was able to offer more than 125,000 job opportunities while more than RM4 billion has been generated by this industry in 2005. Apart from employment and income opportunities, doubtlessly this industry is one of the main players for the nation food security and marine protein provider for community. To further develop this industry, a number of efforts have been taken by the concern parties such as introducing the fishermen allowance, subsidized diesel and and not too forget; the introduction of ICTs.

ICTs such as GPS, sonar, echo sounder, wireless set and mobile phone have been proven to be a good assistant for the fishermen on the sea. These tools assist the fishermen especially in term of time, money and energy saving. Apart from this, concern parties such as Department of Fisheries Malaysia and Fisheries Development Authority Malaysia have created a

Corresponding Author: Hayrol Azril Mohamed Shaffril, Laboratory of Sustainable Development and Agriculture Extension, Institute for Social Science Studies, Universiti Putra Malaysia, Putra Infoport, 43400 Serdang, Selangor Darul Ehsan, Malaysia Tel: 03-89471870 
number of online services for the fishermen and have persistently encouraged them to use it. Among the online services introduced are:

1- e-License http://elesen.lkim.gov.my/SPB/SPBOnline/Menu/i ndex.aspx

2- e-fund http://dananelayan.lkim.gov.my

3- e-declaration http://epengisytiharan.lkim.com.my

4- e-Training http://eservices.dof.gov.my/ePerkhidmatan/index.p hp? $\bmod =$ authentication\&opt $=\operatorname{login} \&$ spage $=1$

5- e-Extension https://eservices.dof.gov.my/ePerkhidmatan/index. php? $\bmod =$ authentication\&opt $=\operatorname{login} \&$ spage $=2$

6- e-Aquaculture https://eservices.dof.gov.my/ePerkhidmatan/index. php? $\bmod =$ authentication\&opt $=\operatorname{login} \&$ spage $=3$

In Malaysia, efforts to develop ICT have been the main focus of the government. The Malaysians are proud with the success ICT projects such as Rural Internet Center and Rural Info Center in encouraging and increasing the ICT usage among the community. Additionally, programs such as Universal Services Provider (USP) and National Broadband Initiatives (NBI) were introduced to provide equal chances to the community to be exposed to ICT. In line with this, a lot of studies have been done to investigate the level of ICT usage among various groups in Malaysia such as village leaders (Samah et al., 2011; D'Silva et al., 2011), rural community (Hassan et al., 2008), farmers (Hassan et al., 2011a), entreprenuers (Hassan et al., 2009) and teachers (Kumar et al., 2009). Nonetheless, there are few studies done on investigating the level of ICT usage among the fishermen in Malaysia, thus a study need to be conducted in fulfilling this gap. However, before conducting the study, a reliable and valid instrument is needed and this has become the main objective of this study which is to investigate the reliability and validity of the instrument developed to measure the ICT usage among fishermen in Malaysia.

Fisheries industry in Malaysia: Fisheries industry is one of the catalysts used to enhance the socio-economic of the community especially those in the rural areas. Recent data provided by the Department of Fisheries Malaysia (DOF) informs that in 2009, this industry was able to offer 125,632 employment opportunities to the local community, majority of them in the rural areas. The number of registered fishermen in Malaysia was increased year by year starting from $2007(99,697)$,
$2008(109,771)$ and $2009(125,632)$ (Table 1). This happened probably due to attractive offers offered by the government; each of the registered fishermen in Malaysia is given RM200 (approximately USD65) as their monthly allowance. A significant increase was recorded after this action.

There are a huge number of registered vessels in Malaysia based on statistic provided in Table 2. In Malaysia, each registered vessels are given their own category. This category depicts how far they can go and type of engine they use. The categories are A (0.1-5.0 miles nautical), B (5.1-12.0 miles nautical), C0 (12.130.0 miles nautical) and $\mathrm{C} 2$ (>30.1 miles nautical). Up to this date, all of the registered vessels in Malaysia are given subsidized diesel and petrol; another wise step taken by the government to attract more people to this industry. As been depicted in Table 2, in 2009 the west coast zone has come out with the highest registered vessels with 21,604 , followed by the Sabah/Sarawak zone $(18,247)$ and the east coast zone $(8,894)$.

As been provided by DOF, in 2005 there were more than 1.2 billion tonne of marine productivity landed in Malaysia. This big number generated more than RM4 billion (approximately USD 1.3 billion) income to the country. Besides the big number on income generated, Table 3 provides us a clear picture that this industry is one of the main protein providers for the community. Fishermen in the west coast zone have landed the biggest number marine productivity with RM 1.825 billion (Approximately USD 608 million).

\begin{tabular}{llllll}
\multicolumn{6}{l}{ Table 1: Number of fishermen working on licensed vessels } \\
\hline Zone & 2005 & 2006 & 2007 & 2008 & 2009 \\
\hline West Coast & 36,018 & 37,682 & 40,831 & 42,848 & 50,755 \\
East Coast & 24,163 & 26,168 & 25,901 & 29,650 & 33,118 \\
Sabah/ & 31,530 & 36,189 & 32,885 & 37,275 & 41,759 \\
Sarawak & & & & & \\
Total & 91,711 & 87,847 & 99,617 & 109,771 & 125,632 \\
\hline
\end{tabular}

Table 2: Number of registered vessels according to zone

\begin{tabular}{llllll}
\hline Zone & 2005 & 2006 & 2007 & 2008 & 2009 \\
\hline West Coast & 15,611 & 17,003 & 17,392 & 17,990 & 21,604 \\
East Coast & 6,4300 & 6,4800 & 6,7690 & 7,4860 & 8,8940 \\
Sabah/ & 13,974 & 14,793 & 15,060 & 15,483 & 18,247 \\
Sarawak & & & & & \\
Total & 36,015 & 38,276 & 39,221 & 40,959 & 48,745 \\
\hline
\end{tabular}

Table 3: Fisheries landing and income generated

\begin{tabular}{lcl}
\hline Zone & $\begin{array}{l}\text { Quantity of landings } \\
\text { in Tonnes (2005) }\end{array}$ & $\begin{array}{l}\text { Values in ringgit } \\
\text { Malaysia (2005) }\end{array}$ \\
\hline West coast & 525,906 & 1.825 billion \\
East coast & 318,642 & 1.077 billion \\
Sabah/Sarawak & 365,052 & 1.113 billion \\
Total & $1,209,601$ & 4.015 billion \\
\hline
\end{tabular}

All of the sources of the Tables were gained from Official Websites of Department of Fisheries Malaysia 2005-2009 
Table 4: ICT Functions at the Sea and its Benefits

\begin{tabular}{ll}
\hline ICT Tools & Functions/benefits \\
\hline GPS & Locating the spots of the fish location, it aids the fishermen to come back accurately to the \\
spotted location whether its daylight or dark. \\
Improve the safety aspects for the fishermen. It helps the fishermen to return to the jetty even in \\
bad weather or at night where vision is restricted, can be assistance to the fishermen due to its \\
ability to warn the fishermen if they are close to the border or dangerous coral reef. \\
Information such as latitude, longitude, altitude, surface speed, sunrise and sunset times and odometer \\
can be gained through this device. \\
Fishermen offered with a complete and current map of the whole fishing area representing the \\
accurate location, extend, density, depth, movement, species and size of all fish shoals. \\
Sonar & Additionally, data regarding sea bottom such as depth, contours, slopes and stones are offered. \\
& Intensify the safety aspects of the fishermen. In case of emergency, wireless set help the fishermen \\
Wireless set & to communicate either with other vessels or/and related agencies, so that immediate action can be taken. \\
& On top of it, they can instantly share information regarding the fishing spots with the others. \\
& Moreover, through wireless set they can deal a better price with the dealer even when they are still on the sea. \\
Computer & For record purposes (ex: profit and loss, species caught, weather condition, markets) \\
Internet & To search, distribute and share fisheries related information such as market price, online applications, \\
& weather conditions, professional advices, loan services, business opportunity, among/between colleague and related agencies \\
Mobile phone & To search, distribute and share fisheries related information such as market price, online applications, weather \\
& conditions, professional advices, loan services, business opportunity, among/between colleague and related agencies. \\
& Moreover, through mobile phone they can deal a better price with the dealer even when they are still on the sea.
\end{tabular}

In line with the purposes of its establishment, ICT has been proven to offer numerous benefits to its users. One of the main benefits offered is to provide persistent and continuous knowledge to the community especially those in the rural areas (Shaffril et al., 2010; Samah et al., 2011; Hassan et al., 2011b). People can easily get information that they want by simply clicking their computer mouse and the power of internet nowadays in providing updated, current and valuable knowledge cannot is boundless. Moreover, according to studies done by Ellie (2006) and Malek et al. (2009), ICT can solve the illiteracy problem among the rural community. In a study done by Mwakaje (2010), ICT can be used to increase the income and productivity of the farmers where he revealed farmers who used ICT gained a better price compared to farmers who do not use ICT. Apart from this, according to Shaffril et al. (2010) ICT can ease the communication process through online services such as e-mail and blog. All of the studies done have proven that ICT has a good impact on the community and similarly ICT also has good impacts on the fishermen. Table 4 provides us with information on what ICT can offer to the fishermen.

Data provided in Table 4 has confirmed to us that ICT offers a lot of benefits and it has something to do with the socio-economic aspects of the fishermen. The use of ICT such as GPS, sonar and echo-sounder will assist the fishermen to locate the exact location of the fish. Having all of these tools with them to the sea means that no more time will be wasted, limited fuel are consumed to search the fish location, less energy spend to search the fish and the most important things is more fish will be brought back to the jetty. Apart from this, the security and safety aspects of the fishermen are strengthened. The functions of wireless set and mobile phone for example will ease the fishermen to communicate with colleague or related agencies if something bad happens to them on the sea. These two ICT tools also allow fishermen to negotiate a better price with dealers even before they are reaching the jetty. Moreover, computer and internet will expose the fishermen to unlimited fisheries information all around the world.

Unified Theory of Acceptance and Use of Technology (UTAUT): One of the pertinent models in understanding ICT usage is UTAUT. It was strengthened from Technology Acceptance Model (TAM). Venkatesh et al. (2003) were responsible in initiating this model. This model has four main variables namely performance expectancy, effort expectancy, social influence and facilitating conditions. All of these variables are main determinants of ICT usage. Moreover, performance expectancy and effort expectancy are used to integrate perceived usefulness and perceived ease of use in the original TAM model. Apart from this, demographic factors (gender, age and experience) and voluntariness of use are included to mediate the impacts of the main variables on usage intention. The theory was initiated based on eight previous models namely (1) Theory of Reasoned Action; (2) Technology Acceptance Model; (3) Motivational Model; (4) Theory of Planned Behaviour; (5) Integration of Planned Behavior/Technology Acceptance Model; (6) Model of PC utilization; (7) Innovation Diffusion Theory and (8) Social Cognitive Theory). Subsequent validation of UTAUT in a longitudinal study revealed that this model is responsible for more than two thirds of the variance in usage intention (Venkatesh et al., 2003) (Fig. 1). 


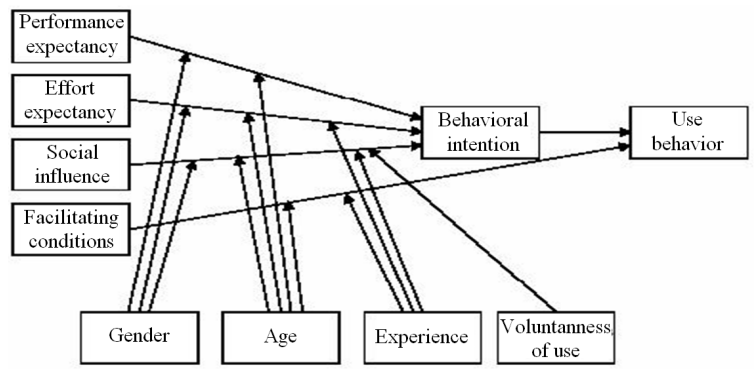

Fig. 1: Unified Theory of Acceptance and Use of Technology (UTAUT)

\section{MATERIALS AND METHODS}

Pre test and reliability: The reliability of an instrument referring to the level of consistency with which it measures whatever is measuring. This quality is important for all types of measurements (Ary et al., 2005). There are several cronbach alpha values that can be considered as reliable. Referring to Cohen et al., (2000) if an instrument reaches an alpha value of 0.60, the instrument is reliable. Nonetheless, Nunnally (1967) has other view when he suggested that if the alpha value of an instrument reach 0.70 and above, it can be considered as reliable. A total of 30 registered fishermen in Port Dickson were chosen as the respondents for the pre-test process. Survey was employed to gain the data needed. Seven enumerators were hired to collect the data needed. For each respondent, a total of $25-45 \mathrm{~min}$ is needed to complete the questionnaire.

Why five likert scale: Sclove (2001) in his study clarified that a five-point likert scales is a common scale used in various studies. Through this type of scale, the points can be labeled as agree strongly, agree somewhat, neutral, disagree somewhat, disagree strongly. This scale can deliberate different patterns of probabilities across a population of potential respondents. Consistency, inconsistency (without polarization) or polarization of response can be constructed through this scale. Through this likert scale, it is easier for the respondents to comprehend the alternatives of answers provided to them compared to the 7 or 10 likert-like scales which can confuse the respondents.

The instruments: The instrument of this study was developed based on the previous studies and literature reviews. The instrument for this study has six parts. The first part (Part A) focuses on the demographic factors of the respondents and consists of 15 questions. The second part of the instrument focuses on the ICT usage on the ship/boat among the fishermen and problems faced in using the ICT (Part B). In this part the fishermen were asked on the possession, level and frequency of ICT usage at the sea. The ICT included in this part are Global Positioning System (GPS), sonar, echo sounder, radar, wireless set and mobile phone. For the problems faced, a total of 15 problems are listed and the respondents are asked to choose the three most frequent problems faced by them in using the ICT.

Part $\mathrm{C}$ of the instrument focuses on the variables affecting ICT usage among the fishermen on the ship/boat. Variables studied are based on the main model of this study which is UTAUT and the variables studied are performance expectancy (12 questions), social influence (8 questions), facilitating condition (6 questions), behavioral intention (7 questions), effort expectancy ( 9 questions) and voluntariness of use (5 questions).

Part D of the instrument focuses on the ICT usage at home among the fishermen and problems faced in using it. A total of 20 ICTs have been included. Among the included ICTs are computer, internet, television, ASTRO, radio, fax machine, playstation, hifi-set, karaoke set, DVD player, VCD player, MP3 Player, mobile phone, telephone (fixed line), digital camera, vidcam, newspaper, book, magazines and IPad. Similar to the questions regarding ICT usage at the sea, the respondents were asked questions pertaining to the ICTs possession, level of usage and frequency of usage. In term of problems faced a total of 15 problems are listed and the respondents are asked to choose the three most frequent problems faced by them in using the ICT.

Questions related to the variables affecting ICT usage among the fishermen at home were included in Part E. Similar to Part C, variables studied are based on the main model of this study which is UTAUT and the factors studied are performance expectancy (9 questions), social influence (8 questions), facilitating condition (6 questions), behavioral intention (9 questions), effort expectancy (9 questions) and voluntariness of use (5 questions).

The last part of the instrument focuses on the usage of fisheries related websites and online services provided by DOF and LKIM. A total of 9 fisheries related websites and 7 online services were listed. Respondents are also asked to write down other websites or online services they have surfed or used.

\section{RESULTS}

Results of pre test: The pre-test for this study was conducted at Port Dickson Jetty and Kampung Panchitan, Port Dickson Negeri Sembilan on 17th June 2011. With the help of officer of Port Dickson Fishermen 
Association, a total of 30 registered fishermen were managed to be gathered at Port Dickson Jetty (10 fishermen) and Panchitan Village (20 fishermen). The Cronbach alpha values of 0.714-0.970 is in line with what have been suggested by Nunnally (1967) and Cohen et al. (2000) who suggested the cronbach alpha value 0.70 or more and 0.60 or more respectively for an instrument to be considered as reliable to be used. The cronbach alpha value for UTAUT (ship/boat) was 0.949 while the cronbach alpha value recorded for UTAUT (home) was 0.928. The highest cronbach alpha value was recorded by voluntariness of use (ship/boat) (0.970) (Table 5).

Table 5: Results of the pre test

\begin{tabular}{lcc}
\hline Variables & No of Item & Cronbach alpha \\
\hline UTAUT (Sea) & 47 & 0.949 \\
Performance Expectancy ship/boat) & 12 & 0.860 \\
Social influence (ship/boat) & 8 & 0.897 \\
Facilitating condition (ship/boat) & 6 & 0.856 \\
Behavioral intention (ship/boat) & 7 & 0.933 \\
Effort Expectancy (ship/boat) & 9 & 0.902 \\
Voluntariness of use (ship/boat) & 5 & 0.970 \\
UTAUT (Home) & 44 & 0.928 \\
Performance Expectancy (home) & 9 & 0.877 \\
Social influence (home) & 8 & 0.813 \\
Facilitating condition (home) & 6 & 0.714 \\
Behavioral intention (home) & 9 & 0.948 \\
Effort Expectancy (home) & 9 & 0.930 \\
Voluntariness of use (home) & 5 & 0.875 \\
\hline
\end{tabular}

\section{DISCUSSION}

Cronbach alpha value produced from the pre-test results have exceeded the recommended values of .70 and 0.60 by Nunnally (1967) and Cohen et al. (2000). Nonetheless, the researchers do feel that some modifications need to be made to further strengthen the instrument. This is essential as it will provide the respondents and the enumerators with more understanding on the instrument. Questions asked on Part C (variables affecting ICT usage among the fishermen on ship/boat) related to performance expectancy of ICT usage and effort expectancy is made more specific. Compared to the previous instrument, questions included in this part are made general and refer to all the ICTs (GPS, sonar, echo sounder, wireless set, radar and mobile phone) the modified instrument are designed specifically referring to each ICT (ship/boat) studied (Table 6 and 7). Furthermore, this study will employ survey method for the actual data collection, therefore selected enumerators are provided with more training to give them deep understanding on the instrument and this will ease them when it comes to actual data collection day.

Table 6: The instrument (Part C: Performance expectancy and effort expectancy) before the pre test.

\begin{tabular}{|c|c|c|c|c|c|}
\hline Performance expectancy & Strongly disagree & Disagree & Moderately agree & Agree & Strongly agree \\
\hline $\begin{array}{l}\text {-Give information on location of the vessel } \\
\text {-Can obtain current fisheries information } \\
\text {-Acquire and store information about the } \\
\text { submerged reef/ fish sink } \\
\text {-Increase income } \\
\text {-Improve safety while at sea } \\
\text {-Assist in shipping } \\
\text {-To gauge the depth of the seabed } \\
\text {-Obtain information on weather at the sea } \\
\text {-Obtain information about the sea condition } \\
\text {-Expand marketing network of my catches } \\
\text {-Accelerate two-way communication with } \\
\text { the relevant agencies } \\
\text {-Facilitate communication at sea }\end{array}$ & 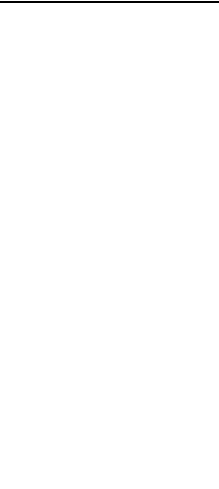 & & 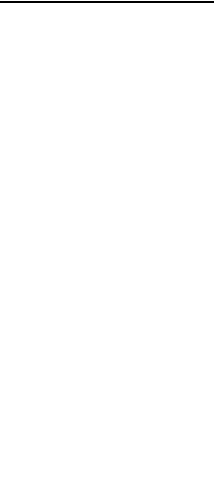 & 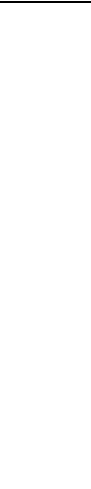 & 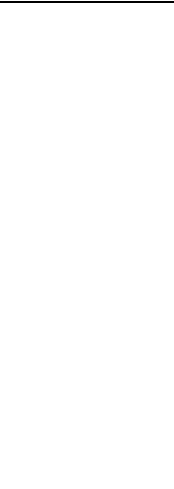 \\
\hline $\begin{array}{l}\text { Effort expectancy } \\
\text {-Save cost } \\
\text {-Enhance work quality } \\
\text {-Increase work productivity } \\
\text {-Saving time } \\
\text {-Improve safety while at sea } \\
\text {-Can forecast weather at sea } \\
\text {-Can forecast situation in sea } \\
\text {-Facilitate marketing } \\
\text {-Can communicate with other } \\
\text { fellow fishermen on fish sink }\end{array}$ & Strongly disagree & Disagree & Moderately agree & Agree & Strongly agree \\
\hline
\end{tabular}


Am. J. Agri. \& Biol. Sci., 7 (1): 21-27, 2012

Table 7: The instrument (Part C: Performance expectancy and effort expectancy) modified based on the suggested modifications.

\begin{tabular}{|c|c|c|c|c|c|}
\hline Performance expectancy & Strongly disagree & Disagree & Moderately agree & Agree & Strongly agree \\
\hline \\
\hline \multicolumn{6}{|l|}{-Learn and enhance ICT skill } \\
\hline \multicolumn{6}{|c|}{-Can obtain current fisheries information } \\
\hline \multicolumn{6}{|c|}{-Acquire and store information about the } \\
\hline \multicolumn{6}{|c|}{ submerged reef/ fish sink } \\
\hline \multicolumn{6}{|l|}{-Increase income } \\
\hline \multicolumn{6}{|l|}{-Improve safety while at sea } \\
\hline \multicolumn{6}{|c|}{-Give information on location of the vessel } \\
\hline \multicolumn{6}{|l|}{ Sonar } \\
\hline \multicolumn{6}{|l|}{-Learn and enhance ICT skill } \\
\hline \multicolumn{6}{|c|}{-Can obtain current fisheries information } \\
\hline \multicolumn{6}{|c|}{-Can track the fish swarm } \\
\hline \multicolumn{6}{|l|}{-Increase income } \\
\hline \multicolumn{6}{|l|}{-Improve safety while at sea } \\
\hline -To gauge the depth of the se & & & & & \\
\hline -Give information on locatiol & & & & & \\
\hline Echo sounder & & & & & \\
\hline -Learn and enhance ICT skil & & & & & \\
\hline -Can obtain current fisheries & & & & & \\
\hline -Can track the fish swarm & & & & & \\
\hline -Increase income & & & & & \\
\hline -Improve safety while at sea & & & & & \\
\hline -To gauge the depth of the se & & & & & \\
\hline -Give information on locatiol & & & & & \\
\hline Radar & & & & & \\
\hline -Obtain information on weatl & & & & & \\
\hline -Obtain information about th & & & & & \\
\hline Wireless set & & & & & \\
\hline -Expand marketing network & & & & & \\
\hline -Accelerate two-way commu & & & & & \\
\hline with the relevant agencies & & & & & \\
\hline -Facilitate communication at & & & & & \\
\hline -Improve safety while at sea & & & & & \\
\hline Mobile phone & & & & & \\
\hline -Expand marketing network & & & & & \\
\hline -Accelerate two-way commu & & & & & \\
\hline the relevant agencies & & & & & \\
\hline -Facilitate communication at & & & & & \\
\hline -Improve safety while at sea & & & & & \\
\hline -Obtain information on fish 1 & & & & & \\
\hline from fellow fishermen & & & & & \\
\hline Effort Expectancy & Strongly Disagree & Disagree & Moderately Agree & Agree & Strongly agree \\
\hline GPS & & & & & \\
\hline -Save cost when at sea & & & & & \\
\hline -Increase work quality & & & & & \\
\hline -Increase catches & & & & & \\
\hline -Saving time & & & & & \\
\hline -Improve safety while at sea & & & & & \\
\hline -Saving energy & & & & & \\
\hline Sonar & & & & & \\
\hline -Save cost when at sea & & & & & \\
\hline -Increase work quality & & & & & \\
\hline -Increase catches & & & & & \\
\hline -Saving time & & & & & \\
\hline -Improve safety while at sea & & & & & \\
\hline -Saving energy & & & & & \\
\hline Echo sounder & & & & & \\
\hline -Save cost when at sea & & & & & \\
\hline -Increase work quality & & & & & \\
\hline -Increase catches & & & & & \\
\hline -Saving time & & & & & \\
\hline -Improve safety while at sea & & & & & \\
\hline -Saving energy & & & & & \\
\hline Radar & & & & & \\
\hline
\end{tabular}


Table 7: Contineus

-Can forecast weather at sea

-Can forecast situation in sea

Wireless set

-Facilitate communications while at sea

-Improve safety while at sea

-Facilitate marketing

-Can communicate with other fellow

fishermen on fish sink

Mobile phone

- Facilitate communications while at sea

-Improve safety while at sea

-Facilitate marketing

-Can communicate with other fellow

fishermen on fish sink

\section{CONCLUSION}

A reliable instrument was made based on the results of the pre-test of this study. The instrument can be used for the actual data collection process of the study in four selected states in Peninsular Malaysia. A number of modifications have been made for the purpose of providing a deeper understanding on the instrument among the enumerators and the respondents. Moreover, enumerators are given more training before they go for the actual data collection process.

\section{REFERENCES}

Ary, D., L.C. Jacobs, A. Razavieh and C.K. Sorensen, 2005. Introduction to Research in Education. 7th Edn., Wardsworth Publishing, California, ISBN10: 0534555373, pp: 608.

Cohen, L., L. Manion and K.R.B. Morrison, 2000. Research Methods in Education. 5th Edn., RoutledgeFalmer, New York, ISBN-10: 0415195411, pp: 446.

D'Silva, J.L., B.A. Samah, H.A.M. Shaffril, M.A. Hassan and M. Badsar, 2011. Determinants of attitude towards information and communication technology usage among rural administrators in using structural equation modeling. Am. J. Applied Sci., 8: 481-485. DOI: 10.3844/ajassp.2011.481.485

Ellie, M., 2006. Using ICT to develop literacy. UNESCO.

Hassan, M.A., B.A. Samah, H.A.M. Shaffril and J.L. D'Silva, 2011a. Socio-demographic factors affecting attitude towards information and communication technology usage. Am. J. Applied. Sci., 8: 547-553. 10.3844/ajassp.2011.547.553

Hassan, M.A., N. Ismail, S.Z. Omar and J. Bolong, 2008. Impact of ICT projects on participants in the rural areas. Pertanika J. Social Sci., 16: 85-94.

Hassan, M.S., H.A.M. Shaffril, M.A. Hassan and J.L. D'Silva, 2009. Developing agriculture in Malaysia: Internet utilization among Malaysian youth agro- businessman. European Journal of Social Science, 11: 215-224.

Hassan, M.S., S.M, Yassin, H.A.M. Shaffril, M.S. Othman and B.A. Samah et al., 2011b. Receiving the agriculture information through mass media and interpersonal sources among the rural community. Am. J. Agric. Biol. Sci., 6: 451-461. DOI: 10.3844/ajabssp.2011.451.461

Kumar, N., R.C. Rose and J.L. D'Silva, 2009. Factors influencing the effective use of technology among Malaysian teachers. Eur. J. Soc. Sci., 6: 108-124.

Malek, J.A., N.A. Razak, J. Aziz, N.F.M. Nor and Z. Amir, 2009. The digital social impact in ICT literacy program for rural community. Proceedings of the 8th WSEAS International Conference on EActivities and Information Security and Privacy, (AISP' 09), WSEAS, Stevens Point, Wisconsin, USA., pp: 20-24.

Mwakaje, A.G., 2010. Information and communication technology for rural farmers market access in Tanzania. J. Inform. Technol. Impact, 10: 111-128.

Nunnally, J.C., 1967. Psychometric Theory. 3rd Edn., McGraw Hill, New York, ISBN: 0071070885, pp: 640.

Samah, B.A., H.A.M. Shaffril, M.A. Hassan and J.L. D'Silva, 2011. Can technology acceptance model be applied on the rural setting: The case of village development and security committee in Malaysia. J. Soc. Sci., 7: 113-119. DOI: 10.3844/jssp.2011.113.119

Sclove, S.L., 2001. Notes on likert scales. Stanley Louis Sclove.

Shaffril, H.A.M., B.A. Samah, M.A. Hassan and J.L. D'Silva, 2010. Socio-economic factors that impinge computer usage in administration works among village leaders in Malaysia. Scientific Res. Essays, 5: 3623-3633.

Venkatesh, V., M.G. Morris, G.B. Davis and F.D. Davis, 2003. User acceptance of information technology: Toward a unified view. MIS Q., 27: 425-478. 